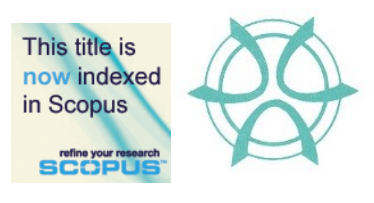

\title{
RECYCLING INTENTION AND BEHAVIOUR AMONG THE HIGHER EDUCATION INSTITUTIONS' (HEIS) COMMUNITY IN MALAYSIA
}

\author{
Nik Nadia Izyan Binti Jamil ${ }^{1}$, Mansor Bin Ibrahim ${ }^{2}$, Khairusy Syakirin \\ Has-yun Hashim ${ }^{3}$, Haruna Babatunde Jaiyeoba ${ }^{4}$ \\ ${ }^{1,4}$ International Institute of Halal Research and Training \\ ${ }^{2,3}$ Kulliyyah of Architecture and Environmental Design \\ INTERNATIONAL ISLAMIC UNIVERSITY MALAYSIA
}

\begin{abstract}
The Higher Education Institutions (HEIs) are among the largest waste producers in the municipality, and they have a huge responsibility towards the waste they produced. In order to divert waste as much as possible from the landfill, many HEIs have implemented reduce, reuse and recycle (3Rs) strategies and programs on their campuses. However, not all the communities are aware of the programs initiated, and as such, the recycling rate in most universities is still low. Therefore, this research seeks to identify the factors that influence the HEIs community to practise recycling on the campus. This study has extended the Theory of Planned Behaviour (TPB) with the inclusion of situational factors, recycling information and personal norm in the model. A total of 1068 duly completed questionnaire surveys were collected from six selected universities. The data collected were analysed using both descriptive and inferential analyses. The findings show that all the constructs investigated significantly influence recycling intention with exception of the subjective norm, whereas the situational factors have a significant direct influence on recycling behaviour. These findings have led to several suggestions and recommendations for a better sustainable waste management on the campuses in Malaysia.
\end{abstract}

Keywords: TPB, sustainable SWM, 3R, recycling behaviour, Higher Education Institutions (HEIs)

\footnotetext{
${ }^{1}$ Corresponding Author. Email: nixnadizy@gmail.com
} 
PLANNING MALAYSIA

Journal of the Malaysia Institute of Planners (2021)

\section{INTRODUCTION}

Higher Education Institutions (HEIs) consist of a large area that can be assumed as a small city that has contributed a lot to solid waste generation in the municipalities (Gallardo et al., 2016). Consequently, HEIs have responsibilities towards supporting various government's initiatives on minimizing waste to the landfill.

Although there are many $3 R$ s initiatives and programmes implemented, the issue of gaining participation and engagement from HEIs' community has become a great challenge. The community's engagement is important for successful recycling practices in the university. However, many of the HEIs community failed to practice 3 Rs and waste minimization as promoted and campaigned. Therefore, this study seeks to identify the significant factors determining recycling intention and behaviour among the HEIs community by adopting modified Theory of Planned Behaviour Theory (TPB).

This study is expected to identify the main cause of the HEIs' community to practice $3 \mathrm{R}$ on the campus. This will help the responsible department or solid waste administrator in the campus to improve their SWM besides to increase the recycling rates through optimum recycling practices in the university. The identification of factors and the relationship of each factor will contribute to the development of appropriate SWM scheme in the campus. The outcome of the generalization of new attitude and behaviour theories will lead to recommendation for better HEIs' solid waste management in the future.

\section{LITERATURE REVIEW}

Waste produced from HEIs is considered as institutional solid waste. According to Izan et al. (2017), waste compositions in Malaysian HEIs consisted of food or organic waste, papers, plastics, tin/ aluminium, polystyrene, and glass. Whereas Wen (2017) found that most waste generated at HEIs is recyclables, whereby this diversified waste needs to be handled prioritize their impacts (Osmond et al. 2013).

Since waste produced in HEIs are mostly recyclables, there are many opportunities for $3 \mathrm{R}$ implementation and practices in the campuses in which a proper system for sustainable SWM especially $3 \mathrm{R}$ initiatives need to be designed appropriately and should integrate and recognize WHP concept to achieve sustainability goals in the campus (Osmond et al., 2013; Ghazvinei et al., 2017).

However, the strategies adopted and implemented in HEIs usually depend on the university itself, several universities focus on energy conversion rather than SWM and some focus on composting rather than other methods of waste reduction. However, many researchers agreed that the strategies should be appropriately developed according to the university's waste composition analysis (Gallardo et al., 2016; Shankar Y \& Khandelwal, 2017; Ghazvinei et al., 2017; Izan et al., 2017; SWCorp, 2019). 
Nik Nadia Izyan Binti Jamil, Mansor Bin Ibrahim, Khairusy Syakirin Has-yun Hashim, Haruna Babatunde Jaiyeoba Recycling Intention and Behaviour Among the Higher Education Institutions' (HEIs) Community in Malaysia

Almost all universities in Malaysia have adopted several strategies for sustainable SWM in the campus. Universiti Kebangsaan Malaysia (UKM) for example has launched the Zero Waste Campus Programme (ZWCP) in 2010 (Norfadillah et al., 2012). Universiti Teknologi Malaysia (UTM) and Universiti Tun Hussein Onn (UTHM) have established several green living laboratories and green or sustainable campus office to promote sustainability in their campuses (Muhamad Nur Fadhli et al., 2018; SCOUTHM, n.d.). University of Malaya (UM) has established UM Zero Waste Campaign (UMZWC) while Universiti Putra Malaysia (UPM) has established a waste bank in the campus (UMZWC, 2019; Fatma et al., 2019).

The establishment of living laboratories, green offices, and waste banks indicate that these universities are giving their full commitment in achieving sustainable SWM on their campuses. In fact, these initiatives also require commitment from the community to uphold the similar aspiration and goals. However, there are many challenges in shaping attitude and behaviour of the university's community to practise 3R. Despite many initiatives implemented to encourage recycling and sustainable behaviour in the campus, the community is still lack of awareness and rarely practicing $3 \mathrm{R}$ on the campus (Mazaitul Shima, Shahirah Umamah, \& Choy, 2015).

\section{CONCEPTUAL FRAMEWORK}

TPB is an established, well-known theory and the most applied behavioural theory in social psychology (Morris et al., 2012; Liu, et al., 2017; Anita, 2019). It was developed by Ajzen (1987) and refined by the Theory of Reason Action which indicates that human behaviours are guided by three kinds of considerations, namely attitude, perceived behaviour control (PBC), and subjective norm ( $\mathrm{SN})$.

TPB is commonly employed in studies related to recycling in which past findings show that TPB's constructs are well-suited to study recycling behaviour (Largo-Wight et al., 2012). However, instead of adopting the original TPB, recently the extended or modified TPB to accommodate environmental studies has been commonly used. Gadiraju (2016) opined that additional variable should be integrated into TPB to maximize the assumption of recycling behaviour intentions besides to increase the variance of the theoretical model. Among the variables that mostly extended TPB for the previous studies are such as situational factors (SF), knowledge, and personal norm (PN).

According to Whitmarsh et al. (2018) SF is one of the strongest reasons for people to recycle. For instance, if recycling facilities are upgraded, it will become more normative and easier to practise. Furthermore, Flanagan (2017) found that adequate facilities have improved recycling habits of the secondary school's students, which indicates convenience has made the students become motivated to recycle more. Many studies resulted significant influence of SF on 
recycling intention and behaviour (Philippsen, 2015; Zhang et al., 2015; Sharifah et al., 2015; Gadiraju, 2016; Heidari et al., 2018; Arli et al., 2020).

Knowledge has been included into TPB by several researchers (Sharifah et al., 2015; Zhang et al., 2015; Aria, 2016; Noralfishah et al., 2019). However, the inclusion of knowledge into TPB only limited to the subjective questions of how and what to recycle. Most of the studies reported significant for influence of knowledge on recycling intention and behaviour except Philippsen (2015). This can be assumed that there was inadequacy of information provided on the campus which leads to lack of knowledge about recycling among the community.

Another variable that was usually extended the TPB is PN. Many studies have extended TPB with the inclusion of PN (Philippsen, 2015; Zhang et al., 2015; Botetzagias et al., 2015; Poskus, 2015; Gadiraju, 2016; Xu et al., 2017; Heidari et al., 2018; Noralfishah et al., 2019; Arli et al., 2020; Nik Hazimah et al., 2020). According to Gadiraju (2016), including personal moral norm or PN in TPB seems to be appropriate and significant at least in the context of recycling behaviour because it shows elements of personal morality and social responsibility. Moreover, all the studies that included PN into TPB found it to be significant towards recycling intention. According to Gadiraju (2016) although the inclusion of PN in TPB was found to be positively influencing recycling intention, it has reduced the significance level of the SN in the model. This indicates that even though the students were influenced by their friends and family's perception of what they were supposed to do, they were more motivated by their norms and moral responsibility.

Based on the above discussion, instead of adopting original TPB, this study has extended TPB with the inclusion of three other factors namely information availability (IA), personal norm (PN), and situational factor (SF). Initially, six constructs were predicted to influence recycling intention and behaviour among the HEI's community. However, during the Exploratory Factor Analysis (EFA) and cross-validation process for the pilot and actual data. PBC was insignificant as it has high correlation with attitude. Therefore, $\mathrm{PBC}$ was excluded from the model. 
Nik Nadia Izyan Binti Jamil, Mansor Bin Ibrahim, Khairusy Syakirin Has-yun Hashim, Haruna Babatunde Jaiyeoba Recycling Intention and Behaviour Among the Higher Education Institutions' (HEIs) Community in Malaysia

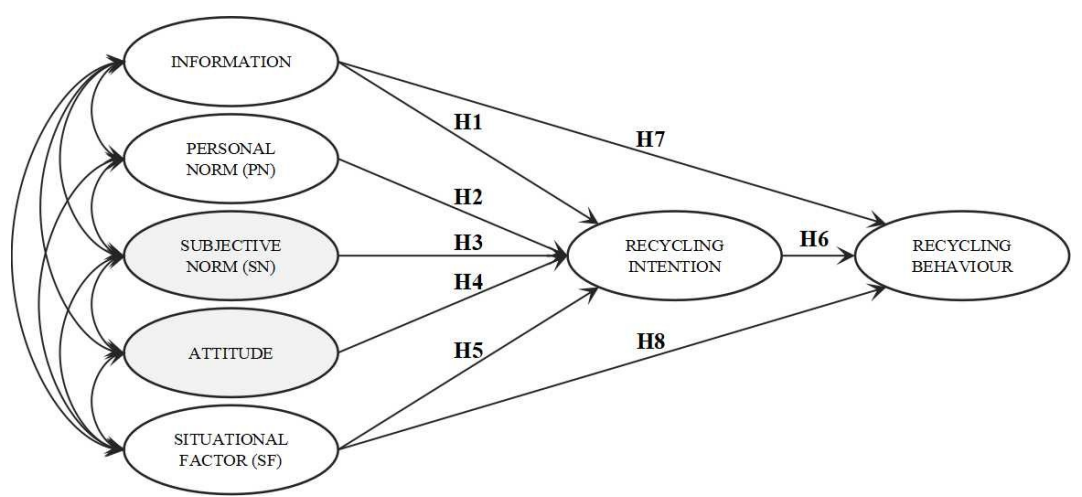

Figure 1: Developed conceptual model for the study

The final developed conceptual model for this study can be seen in Figure 1 in which five constructs (IA, PN, SN, Att., SF) were predicted to have a significant effect on recycling intention.

\section{INSTRUMENTS AND METHODS}

This study adopts quantitative research approach hence, data were collected from six selected universities: Universiti Teknologi Malaysia (UTM), Universiti Tun Hussein Onn Malaysia (UTHM), Universiti Malaya (UM), Universiti Putra Malaysia (UPM), Universiti Kebangsaan Malaysia (UKM), and International Islamic University Malaysia (IIUM). These universities were selected based on their involvement in UI Greenmetric 2019 considering these universities were committed to their sustainable campus agenda.

Specifically, data were collected from the students, administrative staffs, academic staffs, and others who are familiar with the university's surrounding areas. An adequate sample size for this study was arrived based to the formula by Hair et al. (2010) in which the minimum sample size for the developed model is 500 samples. However, to meet the adequacy and avoid bias, the sample size was calculated using an online sample size calculator from Creative Research System for 95\% confidence level with 5.0\% margin error (Creative Research Systems, n.d.) and the data collection was using simple random and cluster sampling.

The selected respondents were given a set of questionnaire survey with the items using a 10-point interval scale measure. A total of 1094 responses were collected during the field survey. However, only 1068 completed questionnaires were valid after the screening.

The data was analysed through descriptive statistics for the respondents' background and inferential statistics to examine the relationship between variables in the developed conceptual model through Structural Equation Modelling (SEM). Prior to SEM, Exploratory Factor Analysis (EFA) 
and Confirmatory Factor Analysis (CFA) were conducted to reduce the items in the questionnaire into manageable sizes as well as to test the validity and reliability of the variables in the model. Meanwhile, EFA, CFA and SEM were analysed using Statistical Package for the Social Sciences (SPSS Version 24) and Analysis of Moment Structure (AMOS Graphic).

To achieve the model fit during the CFA, several items were removed from the model due to low factor loading and following the modification suggestions. For this study, the model fit was examined based on the Root Mean Square Error of Approximation (RMSEA) for the absolute fit, Comparative Fit Index (CFI) for the incremental fit, and Chi-square distribution (Chisq/df) for the parsimonious fit criteria as depicted in Table 1.

Table 1: Chosen criteria for fitness indexes

\begin{tabular}{lcll}
\hline $\begin{array}{c}\text { Name of } \\
\text { Category }\end{array}$ & $\begin{array}{c}\text { Name of } \\
\text { Index }\end{array}$ & \multicolumn{1}{c}{ Level of Acceptance } & \multicolumn{1}{c}{ Literature } \\
\hline Absolute Fit & RMSEA & RMSEA $<0.08$ & $\begin{array}{l}\text { Browne and Cudeck } \\
(1993)\end{array}$ \\
\hline $\begin{array}{l}\text { Incremental } \\
\text { Fit }\end{array}$ & CFI & $\begin{array}{l}\text { CFI }>0.95 \text { (great) } \\
\text { CFI }>0.90 \text { (traditional) } \\
\text { CFI }>0.80 \text { (sometimes }\end{array}$ & Bentler (1990) \\
& & permissible) & \\
\hline Parsimonious & Chisq/df & $\begin{array}{l}\text { Chisq } / \mathrm{df}<3.0 \text { (great) } \\
\text { Chisq } / \mathrm{df}<5.0 \text { (permissible) }\end{array}$ & $\begin{array}{l}\text { Marsh and Hocevar (1985) } \\
\text { Hu and Bentler (1999) }\end{array}$ \\
\hline Fit & & & \\
\hline
\end{tabular}

\section{RESULTS}

\section{Respondents' Background}

For this study, most of the respondents were females with a total of $671(62.83 \%)$ and $393(36.80 \%)$ were males, while others did not indicate their gender. Regarding the age, 625 (66.96\%) respondents are between 16 to 25 years old, indicating that the majority of the respondents are from the students with a total of $721(67.51 \%)$. A total of $440(41.2 \%)$ are between 26 years and above, suggesting that the majority from the group of workers and staffs. There were $746(69.84 \%)$ of the total respondents who experienced less than 1-5 years in the university assumed as the common period for the students and workers in the university followed by $212(19.85 \%)$ who experienced more than 9 years in the university assumed to be lecturers, workers, or postgraduate students. With this data, generally, it has met the requirement of the targeted respondents for this study in which the distributions seem relevant for further analysis.

\section{Confirmatory Factor Analysis (CFA)}

Before conducting SEM, CFA was applied for this study to achieve parsimony. The final model of the factor loading matrix from the EFA was measured for its model fit through Attempt 1 . However, it showed a very poor result. The model 
Nik Nadia Izyan Binti Jamil, Mansor Bin Ibrahim, Khairusy Syakirin Has-yun Hashim, Haruna Babatunde Jaiyeoba Recycling Intention and Behaviour Among the Higher Education Institutions' (HEIs) Community in Malaysia

indices for this measurement showed relative Chi-Square 9.274, CFI 0.837, TLI 0.818 , RMSEA 0.088. Hence, the Attempt 1 measurement model fit was failed to meet the criteria of model fit suggested in Table 1.

Due to a very poor model fit in the Attempt 1 , another attempt for the measurement model was employed with some modification. The measurement model Attempt 2 deleted items with very low factor loading and assessed it modification indices (MI). It was found that the measurement model had too many redundant items which were indicated through MI $>15$. Hence, each highly correlated item was constrained as a free parameter to fix the fitness indexes starting from the highest value (MI) until the required fitness indexes achieved. The summary of achieved fitness indexes for the model can be seen in Table 2 .

Table 2: Summary of Fitness Indexes for Measurement Model (Attempt 2)

\begin{tabular}{|c|c|c|c|}
\hline $\begin{array}{c}\text { Name of } \\
\text { Category }\end{array}$ & $\begin{array}{c}\text { Name of } \\
\text { Index }\end{array}$ & $\begin{array}{c}\text { Index } \\
\text { Value }\end{array}$ & Interpretation \\
\hline \multirow{2}{*}{$\begin{array}{c}\text { Farsimonious } \\
\text { Fit }\end{array}$} & CMIN & 1845.554 & -- \\
\cline { 2 - 4 } & DF & 375 & -- \\
\cline { 2 - 4 } Incremental Fit & CMIN/DF & $\mathbf{4 . 9 2 1}$ & The permissible level is achieved \\
\hline Absolute Fit & RMSEA & $\mathbf{0 . 9 3 1}$ & The required level is achieved \\
\hline & SRMR & $\mathbf{0 . 0 6 7}$ & The required level is achieved \\
\hline
\end{tabular}

This also indicates that the measurement model (Attempt 2) had met the minimum required model fit. Table 4 indicates the summary of CFA report for measurement model Attempt 2.

According to table 3 , although a few factor loadings were too low, it was valid according to some literature that accepts factor loading between 0.4 to 0.7 if the CR and AVE are satisfactory (Hair et al., 2014). It is opined that if AVE is above 0.4 , but composite reliability (CR) is higher than 0.6 , the convergent validity of the construct is still adequate (Fornell \& Larcker, 1981). Based on the Table 4, the CR of all constructs was above 0.6 , and AVE above 0.5 , therefore the convergent validity of the constructs was considered satisfactory.

Table 3: The summary of CFA Report for measurement model 2

\begin{tabular}{|l|c|c|c|c|}
\hline \multirow{4}{*}{ Construct } & Item & $\begin{array}{c}\text { Factor } \\
\text { Loading }\end{array}$ & \multirow{2}{*}{ CR (Min 0.6) } & $\begin{array}{c}\text { AVE (Min } \\
\text { 0.5) }\end{array}$ \\
\hline \multirow{3}{*}{ Intention } & Int1 & 0.66 & \multirow{2}{*}{$\mathbf{0 . 8 2 9}$} & \multirow{2}{*}{$\mathbf{0 . 5 5 6}$} \\
\cline { 2 - 3 } & Int2 & 0.56 & & \\
\cline { 2 - 3 } & Int3 & 0.90 & \multirow{2}{*}{$\mathbf{0 . 8 5 6}$} & \multirow{2}{*}{$\mathbf{0 . 5 4 9}$} \\
\cline { 2 - 3 } $\begin{array}{l}\text { Personal } \\
\text { Norm }\end{array}$ & Int4 & 0.81 & & \\
\cline { 2 - 3 } & PN1 & Deleted & & \\
\cline { 2 - 3 } & PN2 & 0.75 & & \\
\cline { 2 - 3 } & PN3 & 0.82 & & \\
\hline
\end{tabular}


PLANNING MALAYSIA

Journal of the Malaysia Institute of Planners (2021)

\begin{tabular}{|c|c|c|c|c|}
\hline Construct & Item & $\begin{array}{c}\text { Factor } \\
\text { Loading }\end{array}$ & CR (Min 0.6) & $\begin{array}{c}\text { AVE (Min } \\
0.5)\end{array}$ \\
\hline & PN5 & 0.74 & & \\
\hline & PN6 & 0.54 & & \\
\hline \multirow{4}{*}{ Behaviour } & Beh1 & 0.90 & \multirow{4}{*}{0.881} & \multirow{4}{*}{0.653} \\
\hline & Beh2 & 0.71 & & \\
\hline & Beh3 & 0.91 & & \\
\hline & Beh4 & 0.69 & & \\
\hline \multirow{7}{*}{$\begin{array}{l}\text { Situational } \\
\text { Factor }\end{array}$} & SF1 & Deleted & \multirow{7}{*}{0.880} & \multirow{7}{*}{0.561} \\
\hline & SF2 & 0.74 & & \\
\hline & SF3 & 0.84 & & \\
\hline & SF4 & 0.87 & & \\
\hline & SF5 & 0.83 & & \\
\hline & SF6 & 0.40 & & \\
\hline & SF7 & 0.72 & & \\
\hline \multirow{3}{*}{ Information } & Info1 & 0.89 & \multirow{3}{*}{0.935} & \multirow{3}{*}{0.827} \\
\hline & Info2 & 0.95 & & \\
\hline & Info3 & 0.88 & & \\
\hline \multirow{6}{*}{ Attitude } & Att1 & 0.61 & \multirow{6}{*}{0.820} & \multirow{6}{*}{0.501} \\
\hline & Att2 & Deleted & & \\
\hline & Att3 & 0.77 & & \\
\hline & Att4 & 0.84 & & \\
\hline & Att5 & 0.69 & & \\
\hline & Att6 & 0.50 & & \\
\hline \multirow{5}{*}{$\begin{array}{l}\text { Subjective } \\
\text { Norm }\end{array}$} & SN1 & Deleted & \multirow{5}{*}{0.732} & \multirow{5}{*}{0.509} \\
\hline & $\mathrm{SN} 2$ & 0.83 & & \\
\hline & $\mathrm{SN} 3$ & 0.83 & & \\
\hline & $\mathrm{SN} 4$ & 0.35 & & \\
\hline & SN5 & Deleted & & \\
\hline
\end{tabular}

\section{Discriminant Validity Summary}

Next, the measurement model was also assessed for its validity, and reliability before modelling the structural model. Table 4 indicates the Discriminant Validity Index Summary to show and prove the constructs in the model were discriminant between each other.

Table 4: The Discriminant Validity of Construct

\begin{tabular}{|l|c|c|c|c|c|c|c|c|c|c|c|}
\hline & CR & AVE & MSV & MaxR(H) & Int. & PN & Beh. & SF & IA & Att. & SN \\
\hline Int. & 0.829 & 0.556 & 0.412 & 0.882 & $\mathbf{0 . 7 4 6}$ & & & & & & \\
\hline Per.Norm & 0.856 & 0.549 & 0.387 & 0.875 & 0.622 & $\mathbf{0 . 7 4 1}$ & & & & & \\
\hline Beh. & 0.881 & 0.653 & 0.416 & 0.916 & 0.642 & 0.493 & $\mathbf{0 . 8 0 8}$ & & & & \\
\hline Sit.Fac. & 0.880 & 0.561 & 0.501 & 0.910 & 0.533 & 0.480 & 0.645 & $\mathbf{0 . 7 4 9}$ & & & \\
\hline Info. & 0.935 & 0.827 & 0.501 & 0.944 & 0.439 & 0.281 & 0.525 & 0.708 & $\mathbf{0 . 9 1 0}$ & & \\
\hline Att. & 0.820 & 0.501 & 0.251 & 0.854 & 0.393 & 0.501 & 0.121 & 0.177 & 0.063 & $\mathbf{0 . 6 9 5}$ & \\
\hline Sub.Norm & 0.732 & 0.509 & 0.287 & 0.823 & 0.392 & 0.454 & 0.448 & 0.536 & 0.454 & 0.229 & $\mathbf{0 . 7 0 9}$ \\
\hline
\end{tabular}


Nik Nadia Izyan Binti Jamil, Mansor Bin Ibrahim, Khairusy Syakirin Has-yun Hashim, Haruna Babatunde Jaiyeoba Recycling Intention and Behaviour Among the Higher Education Institutions' (HEIs) Community in Malaysia

Referring to Table 4 above, the diagonal values (in bold) are a square root of AVE of the construct while other values show the correlation between the respective constructs. The diagonal values have shown higher values than the values in its row and column, thus, it can be concluded that the discriminant validity for all seven constructs was achieved.

\section{Structural Equation Modelling}

As the model fitness indexes and all the criteria were satisfied, this model was proceeded with Structural Equation Modelling (SEM). SEM was employed and the structural model was obtained as in Figure 2.

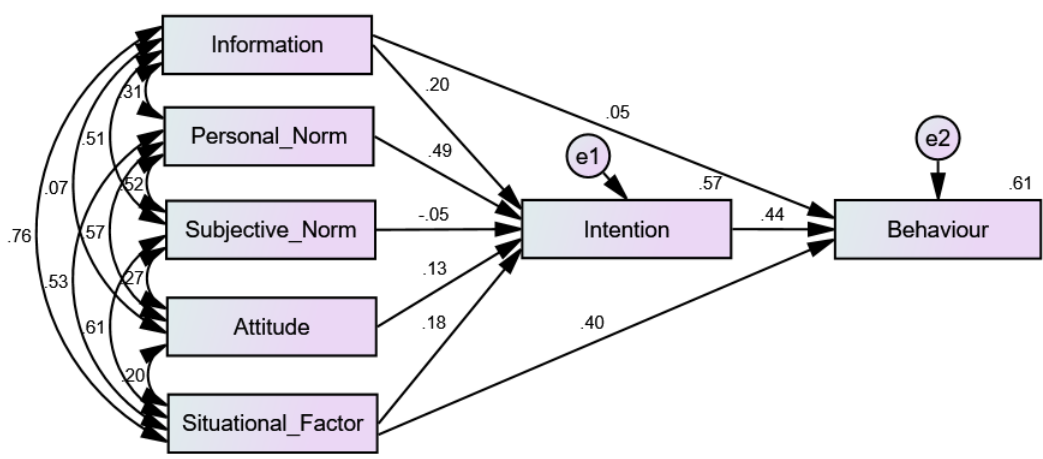

Figure 2: The standardized coefficient regression weights or factor loading for every path in the complete model

Figure 2 shows the standardized estimate for the structural model for this research. The highest measure of correlation was resulted between IA and SF with the measure 0.76 . This can be interpreted that the discriminant validity between exogenous constructs was achieved as all the measures were below 0.85 . If any of two exogenous constructs were highly correlated (measure $>0.85$ ), the discriminant validity had failed, in other words, the constructs cannot be treated separately as they are redundant.

The most important output in the Standardized Regression Weight is the value of $\mathrm{R}^{2}$ in the model (Zainudin, 2016). From the Figure 2 the value of coefficient of determination $\mathrm{R}^{2}$ for the model was 0.61 . This figure indicates the contribution of exogenous constructs (IA, PN, SN, Att., SF, and Int.) in estimating the endogenous constructs of behaviour to recycle was $61 \%$. At the same time, $\mathrm{R}^{2}$ for the intention to recycle was 0.57 , which indicates $57 \%$ of the intention to recycle could be measured by using 5 latent constructs including IA, PN, SN, Att., SF. 
Table 5: The regression path coefficients and its significance based on $\mathrm{P}$-value $<0.05$ for the complete model

\begin{tabular}{|c|c|c|c|c|c|c|c|}
\hline \multicolumn{3}{|c|}{ Path of the Constructs } & Estimate & S.E. & C.R. & $\mathbf{P}$ & Label \\
\hline Intention & $<---$ & Information & .180 & .028 & 6.513 & $* * *$ & \\
\hline Intention & $<---$ & Personal_Norm & .665 & .041 & 16.406 & $* * *$ & \\
\hline Intention & $<---$ & Subjective_Norm & -.110 & .064 & -1.717 & .086 & \\
\hline Intention & $<---$ & Attitude & .272 & .052 & 5.191 & $* * *$ & \\
\hline Intention & $<---$ & Situational_Factor & .175 & .036 & 4.911 & $* * *$ & \\
\hline Behaviour & $<---$ & Intention & .400 & .022 & 18.476 & $* * *$ & \\
\hline Behaviour & $<---$ & Situational_Factor & .368 & .029 & 12.732 & $* * *$ & \\
\hline Behaviour & $<---$ & Information & .037 & .024 & 1.546 & .122 & \\
\hline
\end{tabular}

Table 5 shows the regression path coefficient and its significance based on P-value $<0.05$ for the complete model. The result showed that all paths of the constructs were significant except for the $\mathrm{SN} \rightarrow$ intention and IA $\rightarrow$ behaviour. Thus, the interpretation of these results for the hypotheses developed is depicted in Table 6 below.

Table 6: The result of hypotheses testing for the respective path

\begin{tabular}{|c|c|c|c|c|}
\hline Hypotheses & Path & $\mathbf{C R}$ & $\mathbf{P}$ & Decision \\
\hline $\begin{array}{l}\text { H1. Information availability has positive } \\
\text { influence towards recycling intention }\end{array}$ & IA $\rightarrow$ Int & 6.513 & $* * *$ & Supported \\
\hline $\begin{array}{l}\text { H2. Personal norm has positive influence } \\
\text { towards recycling intention }\end{array}$ & $\mathrm{PN} \rightarrow \mathrm{Int}$ & 16.406 & $* * *$ & Supported \\
\hline $\begin{array}{l}\text { H3. Subjective norm has positive } \\
\text { influence towards recycling intention }\end{array}$ & $\mathrm{SN} \rightarrow \mathrm{Int}$ & -1.717 & .086 & $\begin{array}{c}\text { Not } \\
\text { Supported }\end{array}$ \\
\hline $\begin{array}{l}\text { H4. Attitude has positive influence } \\
\text { towards recycling intention }\end{array}$ & $\mathrm{Att} \rightarrow \mathrm{Int}$ & 5.191 & $* * *$ & Supported \\
\hline $\begin{array}{l}\text { H5. Situational factor has positive } \\
\text { influence towards recycling intention }\end{array}$ & $\mathrm{SF} \rightarrow$ Int. & 4.911 & $* * *$ & Supported \\
\hline $\begin{array}{l}\text { H6. Recycling intention has positive } \\
\text { influence towards recycling behaviour }\end{array}$ & Int $\rightarrow$ Beh & 18.476 & $* * *$ & Supported \\
\hline $\begin{array}{l}\text { H7. Information availability has positive } \\
\text { direct influence towards recycling } \\
\text { behaviour }\end{array}$ & $\mathrm{IA} \rightarrow$ Beh. & 1.546 & .122 & $\begin{array}{c}\text { Not } \\
\text { Supported }\end{array}$ \\
\hline $\begin{array}{l}\text { H8. Situational factor has positive direct } \\
\text { influence towards recycling behaviour }\end{array}$ & $\mathrm{SF} \rightarrow \mathrm{Beh}$. & 12.732 & $* * *$ & Supported \\
\hline
\end{tabular}

\section{DISCUSSION OF FINDINGS}

From the hypotheses in the previous section, this study found four significant factors influencing recycling intention and behaviour of the HEIs' community in Malaysia which were IA, PN, attitude and SF, while SN was not significantly 
Nik Nadia Izyan Binti Jamil, Mansor Bin Ibrahim, Khairusy Syakirin Has-yun Hashim, Haruna Babatunde Jaiyeoba Recycling Intention and Behaviour Among the Higher Education Institutions' (HEIs) Community in Malaysia

contributed towards recycling intention and behaviour of the community. The sequence of the most influential factors to the least influential factor is first the PN, followed by IA, SF ad attitude while SF has a direct influence on recycling behaviour.

The result shows that most of the HEIs' communities felt guilty and wrong if they do not practice recycling. It also indicates that the person with high motivation and positive moral norms has a great attitude and effort towards recycling compared to those who have lower self-motivation towards recycling.

From this study, as PN is the most influential factor towards recycling intention, there is a need to nurture recycling personal norm or the sense of guilt and responsibility among the community to encourage more recycling behaviour on the campus.

However, to nurture great PN among the community is also a huge challenge. As IA is the second most influential factor towards recycling intention, it can be suggested that the availability of effective information channel is very important to give knowledge and awareness on recycling in the campus. An effective information delivery will help to nurture the sense of responsibility among the community.

In fact, SF with the provision of good and adequate facilities alone does not guarantee the community will recycle more although based on the result it can be understood that the community will recycle unintendedly if there are facilities provided near them. But they also tend to recycle incorrectly.

\section{CONCLUSION}

This study found four significant factors influencing recycling intention and behaviour of the HEIs' community in Malaysia in which PN resulted in the highest influence on recycling intention followed by IA, SF and attitude. SF had a direct effect towards recycling behaviour while IA had no direct positive effect towards recycling behaviour. This study suggests that enhancing PN among HEIs' community will increase recycling behaviour on the campuses, in which PN can be improved by the availability of adequate and effective recycling information and facilities on the campuses. The future research was recommended extending the theory by including spiritual aspects or religious ethics as well as policy and enforcement in influencing recycling intention and behaviour in HEIs.

\section{ACKNOWLEDGEMENT}

The study was made possible with research grant awarded by the Ministry of Higher Education through the NRGS13-002-0002.

\section{REFERENCES}

Ajzen, I. (2005). Attitudes, Personality and Behaviour (2nd Edition). Open University Press. 
Anita, K. (2019). Exploring young adults' e-waste recycling behaviour using an extended theory of planned behaviour model: A cross-cultural study. Resources, Conservation and Recycling, 141(October 2018), 378-389.

Arya, B., \& Chaturvedi, S. (2020). Extending the theory of planned behaviour to explain energy saving behaviour. Environmental and Climate Technologies, 24(1), 516528.

Arli, D., Badejo, A., Carlini, J., France, C., Jebarajakirthy, C., Knox, K., Pentecost, R., Perkins, H., Thaichon, P., Sarker, T., \& Wright, O. (2019). Predicting intention to recycle on the basis of the theory of planned behaviour. International Journal of Nonprofit and Voluntary Sector Marketing, 25(2).

Botetzagias, I., Dima, A. F., \& Malesios, C. (2015). Extending the Theory of Planned Behavior in the context of recycling: The role of moral norms and of demographic predictors. Resources, Conservation and Recycling, 95, 58-67.

Creative Research Systems. (n.d.). The Survey System, Research Aids: Sample Size Calculator. Retrieved from https://www.surveysystem.com/sscalc.htm

Flanagan, S. (2017). How Can Education Improve the Recycling Behaviors and Attitudes of Middle School Students? [Master's thesis, School of Education Hamline University] DigitalCommons@Hamline

Gadiraju, T. (2016). Investigating the Determinants of Recycling Behavior in Youth by Using Theory of Planned Behavior. [Master's thesis, University of South Florida] Graduate Theses and Dissertations: Scholar Commons.

Gallardo, A., Edo-Alcón, N., Carlos, M., \& Renau, M. (2016). The determination of waste generation and composition as an essential tool to improve the waste management plan of a university. Waste Management, 53, 3-11.

Ghazvinei, P. T., Mir, M. A., \& Darvishi, H. H. (2017). University Campus Solid Waste Management: Combining Life Cycle Assessment and Analytical Hierarchy Process (Briefs of Env. Sc.). Springer International Publishing AG.

Hair, J.F., Black, W.C., Babin, B.J., \& Anderson, R.E. (2010). Multivariate Data Analysis. ( $7^{\text {th }}$ ed.). Prentice Hall, Upper Saddle River, New Jersey

Heidari, A., Kolahi, M., Behravesh, N., Ghorbanyon, M., Ehsanmansh, F., Hashemolhosini, N., \& Zanganeh, F. (2018). Youth and Sustainable Waste Management: a SEM Approach and Extended Theory of Planned Behavior. Journal of Material Cycles and Waste Management, 20(4), 2041-2053.

Izan, J., Tengku Azmina, I., Noor Hayati, M. I., \& Nor Syuhada, M. Z. (2017). Waste Audit in UMT Campus: Generation and Management of Waste in Cafeteria and Food Kiosk. Journal of BIMP-EAGA Regional Development, 3(1), 84-94.

Largo-Wight, E., Bian, H., \& Lange, L. (2012). An Empirical test of an expanded version of the theory of planned behavior in predicting recycling behavior on campus. American Journal of Health Education, 43(2), 66-73.

Liu, Y., Sheng, H., Mundorf, N., Redding, C., \& Ye, Y. (2017). Integrating norm activation model and theory of planned behavior to understand sustainable transport behavior: Evidence from China. International Journal of Environmental Research and Public Health, 14(12).

Mazaitul Shima, M., Shahirah Umamah, A. M., \& Choy, E. A. (2015). Student attitudinal factors in the creation of sustainable campus: The case of the Universiti Kebangsaan Malaysia. Malaysian Journal of Society and Space 11(8), 52-65. 
Nik Nadia Izyan Binti Jamil, Mansor Bin Ibrahim, Khairusy Syakirin Has-yun Hashim, Haruna Babatunde Jaiyeoba Recycling Intention and Behaviour Among the Higher Education Institutions' (HEIs) Community in Malaysia

Morris, J., Marzano, M., Dandy, N., \& O’Brien., L. (2012). Theories and models of behaviour and behaviour change. Forest Research: Surrey, United Kingdom, 127.

Muhamad Nur Fadhli, M., Norhidayah, M. Y., Abdullah, S., \& Norahim, I. (2018). UTM Student Awareness Towards Solid Waste Segregation in Residential College. Sistem, Sumber Manusia Dan Organisasi Cemerlang (Prosiding Konvensyen Kepengetahuan Dan Felo Penghuni Kolej Kediaman Universiti Awam Kebangsaan), 165-174.

Noralfishah, S., Chan, S. W., \& Ong, Y. S. (2019). Factors influencing recycling intention among university students. International Journal of Innovative Technology and Exploring Engineering, 8(8), 336-340.

Norfadillah, D., Halimaton Saadiah, H., Noraziah, A., \& Sarah, A. (2012). UKM as a sustainable campus: A preliminary inquiry into the knowledge, awareness, and participation of students and staff. Malaysia Journal Society and Space, 8(8), 7690.

Nik Hazimah N.M., Monizaihasra M., Fawehinmi, O., Yusliza, M., \& Jumadil, S. (2020). Investigating the Antecedents of Students' Pro- Environmental Behaviour in the Malaysian Public, 12(3), 1953-1969.

Osmond, P., Dave, M., Prasad, D., Li, F., \& Clayton, J. (2013). Greening Universities toolkit: Transforming universities into green and sustainable campuses-A toolkit for implementers. United Nations Environment Programme (UNEP). http://unep.org/Training/docs/Greening_University_Toolkit.pdf (Last Accessed January 15, 2016).

Philippsen, Y. (2015). Factors influencing students' intention to recycle.

Poskus, M. S. (2015). Predicting recycling Behavior by including moral norms into the theory of planned behavior. Psichologija, 52(52), 22.

SCOUTHM. (n.d.). Introduction: Sustainable Campus Office@UTHM. Accessed February 9, 2021. https://scu.uthm.edu.my/introduction/.

Shankar S.Y., Rachit Khandelwal, (2017) Sustainable waste management strategy for a campus: a case study of JUET, Guna, Management of Environmental Quality: An International Journal, Vol. 28 Issue: 5, pp.610-623,

Sharifah, N. M. S. H., Rosta, H., \& Hock, L. K. (2015). Application of Theory of Planned Behavior in Measuring the Behavior to Reduce Plastic Consumption Among Students at Universiti Putra Malaysia, Malaysia. Procedia Environmental Sciences, 30, 195-200.

SWCorp. (2019). Kompendium Pengurusan Sisa Pepejal Malaysia 2019.pdf. Putrajaya: Perbadanan Pengurusan Sisa Pepejal dan Pembersihan Awam (SWCorp).

UMZWC. (2019). Universiti Malaya Zero Waste Campaign: Annual Report 2019. Kuala Lumpur.

Whitmarsh, L. E., Haggar, P., \& Thomas, M. (2018). Waste reduction behaviors at home, at work, and on holiday: What influences behavioral consistency across contexts? Frontiers in Psychology, 9(Issue: December), 1-13.

Xu, L., Ling, M., Lu, Y., \& Shen, M. (2017). Understanding household waste separation behaviour: Testing the roles of moral, past experience, and perceived policy effectiveness within the theory of planned behaviour. Sustainability (Switzerland), 9(4). 
Xu, L., Ling, M., Lu, Y., \& Shen, M. (2017). Understanding household waste separation behaviour: Testing the roles of moral, past experience, and perceived policy effectiveness within the theory of planned behaviour. Sustainability (Switzerland), $9(4)$.

Zainudin., Awang (2016). SEM Made Simple: A Gentle Learning to Structural Equation Modelling. Selangor: MPWS Rich Publication.

Zhang, D., Huang, G., Yin, X., \& Gong, Q. (2015). Residents' waste separation behaviors at the source: Using SEM with the theory of planned behavior in Guangzhou, China. International Journal of Environmental Research and Public Health, 12(8), 9475-9491.

Received: $5^{\text {th }}$ November 2021. Accepted: $5^{\text {th }}$ December 2021 